INTERNATIONAL JOURNAL OF CURRENT RESEARCH IN CHEMISTRY AND PHARMACEUTICAL SCIENCES

(p-ISSN: 2348-5213: e-ISSN: 2348-5221)

www.ijcrcps.com

DOI: 10.22192/ijcrcps

Coden: IJCROO(USA)

Volume 7, Issue 7 - 2020

Research Article

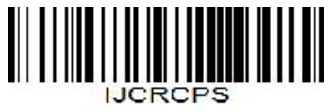

DOI: http://dx.doi.org/10.22192/ijcrcps.2020.07.07.002

\title{
Development of Gold Electrode Modified With Sodium Diethyldithiocarbamate-Nafion to Determine Selenium (IV) in Bulk and in Dosage Formulations Using Differential Pulse Anodic Stripping Voltammetric Analysis
}

\author{
Abdul Aziz Ramadan ${ }^{1 *}$, Hasna Mandil ${ }^{2}$, Abdul Rahman Shikh-Debes ${ }^{3}$ \\ Department of Chemistry, Faculty of Science, University of Aleppo, Syria. \\ *11E-mail: dramadan@scs-net.org or dramadan1946@gmail.com; \\ ${ }^{2}$ E-mail: promandi1955@gmail.com,3E-mail: abd.sh.d@hotmail.com
}

\begin{abstract}
The effect of gold electrode modified with sodium diethyldithiocarbamate-Nafion $\left(\mathrm{GEM}_{\mathrm{DDTC}} \mathrm{N}\right)$ on determination of selenium (IV) using differential pulse anodic stripping voltammetric analysis (DPASVA) was studied. Various parameters (electrolyte, deposition time, pulse duration, pulse amplitude, etc.) affecting the Se(IV) determination were examined. Selenium (IV) was determined in an aqueous $\mathrm{HClO}_{4}(0.1 \mathrm{M})$ and $\mathrm{HCl}(0.002 \mathrm{M})$ medium of $\mathrm{pH} 0.22$ at an accumulation potential of $-350 \mathrm{mV}$ (vs. $\mathrm{Ag} / \mathrm{AgCl}$ ) and an accumulation time of $200 \mathrm{~s}$. Under the optimum conditions, liner calibration graph, $\mathrm{I}_{\mathrm{p}}=\mathrm{f}\left(\mathrm{C}_{\left.\mathrm{Se}{ }^{4+}\right)}\right.$ was obtained in the concentration ranges of $2.5 \times 10^{-8} \mathrm{M}(1.974 \mathrm{ng} / \mathrm{mL})$ to $1 \times 10^{-6} \mathrm{M}(78.96 \mathrm{ng} / \mathrm{mL})$ with relative standard deviations (RSD) $\leq 4.0 \%$. This method showed a good accumulation efficiency for selenium and good resistance to interferences from metal ions as well as those associated with selenium in pharmaceuticals. The results for the determination of $\mathrm{Se}^{4+}$ using $\left(\mathrm{GEM}_{\mathrm{DDTC}} \mathrm{N}\right)$ was more sensitive and accurate than that obtained using bare gold, $G M_{D A N} N$ and $G_{E M}{ }_{\mathrm{OPDA}} \mathrm{N}$ electrodes (the sensitivity was increased about 4000 times and about 2 times, respectively).
\end{abstract}

Keywords: Sodium Diethyldithiocarbamate, Nafion, Selenium, Differential pulse anodic stripping voltammetry 


\section{Introduction}

A new sensitive and selective pulse polarographic method for the determination of Se(IV) next to interfering ions is described. This method is based on the highly sensitive peak formed by the reaction of $\mathrm{Se}(\mathrm{IV})$ with o-phenylenediamine in Britton-Robinson buffer solution $(\mathrm{pH} \mathrm{2.5)}$ at 0.08 $\mathrm{V}$ (vs. $\mathrm{Ag} / \mathrm{AgCl}$ ). A linear calibration graph is obtained for $\mathrm{Se}(\mathrm{IV})$ at a concentration of $5.0 \mathrm{x}$ $10^{-8}$ to $6.8 \times 10^{-5} \mathrm{M}[1]$.

The adsorptive voltammetric behavior of Se(IV) on the hanging mercury drop electrode (HMDE) in the presence of o-phenylenediamine (o-PDA) has been investigated. Experimental results show that the $\mathrm{Se}$ (IV) complex with o-PDA can be adsorbed on the surface of the HMDE, yielding two peaks at $-0.13 \mathrm{~V}$ and $-0.62 \mathrm{~V}$ (vs. $\mathrm{Ag} / \mathrm{AgCl}$ ). The detection limit of the adsorption voltammetry, established from the second peak at $-0.62 \mathrm{~V}$, is as low as $4 \times 10^{-10} \mathrm{~mol} / \mathrm{L}$ [2].

The performance of a poly(1,8diaminonaphthalene)-modified gold electrode (pDAN-Au) for the determination of the selenium(IV) ion in an aqueous medium was investigated with anodic stripping voltammetry without the pretreating of the sample. The detection limit employing the anodic stripping differential pulse voltammetry was $9.0 \times 10^{-9} \mathrm{M}$ for $\mathrm{Se}(\mathrm{IV})$ [3].

Differential pulse cathodic stripping voltammetric determination of selenium from pharmaceutical products was applied. The peak potential is -0.545 $\mathrm{V}$ (vs. $\mathrm{Ag} / \mathrm{AgCl}$ ), and the calibration curve is linear up to $0.125 \mathrm{ng} . \mathrm{mL}^{-1}$, but selenium was determined in the range 8 to $64 \mathrm{ng} \cdot \mathrm{mL}^{-1}$ in pharmaceutical products [4].

The o-phenylenediamine in situ modified electrode, which was used to detect the trace selenium in the human body was studied. The detection limit is $3.2 \times 10^{-9} \mathrm{~mol} / \mathrm{L}$ and the average percentage of recovery is $97.0 \pm 4.3 \%$ [5].
Electropolymerization of 3,3'-diaminobenzidine on a gold surface gave an adherent, stable film of poly(3,3'-diaminobenzidine) (PDAB). This polymer film retained the complexational functionalities of its monomer, demonstrating preconcentration abilities for several ions, including Se(IV) and Te(IV). In particular, in this work, continuous flow and flow injection methods were developed for the sensitive and selective determination of Te(IV). The optimized method for the continuous flow mode had a detection limit of $5.6 \times 10^{-9} \mathrm{~mol} / \mathrm{L}$ for $10 \mathrm{~min}$ preconcentration [6].

Determination of Se(IV) was investigated on 3,3'diaminobenzidine/Nafion/ mercury film modified glass carbon electrode (DNMFE). The 3,3'diaminobenzidine/Nafion coating solution was irradiated by a tungsten light bulb to oxidize the 3,3'-diaminobenzidine. This coating solution was then spin-coated onto glass carbon electrode. Mercury was electrodeposited onto the electrode surface. Se(IV) was preconcentrated onto the DNMFE from the sample solution saturated with EDTA at an accumulation potential of $-0.350 \mathrm{~V}$, and determined by cathodic square-wave stripping voltammetry (SWSV). The analytical signal was linear from 1 to $300 \mathrm{~g} / \mathrm{L}$ with $5 \mathrm{~min}$ accumulation [7].

Differential pulse anodic stripping voltammetric determination of selenium (IV) using a vitamin ENafion modified gold electrode has been studied. Selenium (IV) was determined. Liner calibration graph was obtained in the concentration ranges of $5 \times 10^{-8}-1 \times 10^{-5} \mathrm{~mol} / \mathrm{L}$ with relative standard deviations (RSD) $4.5 \%$ [8].

Differential pulse anodic stripping voltammetric analysis of selenium(IV) using a gold electrode modified with 3,3'-diaminobenzidine.4HCl-nafion (GEMDN) has been studied. Selenium(IV) was determined. Liner calibration graph was obtained in the concentration ranges of $5 \times 10^{-9} \mathrm{M}$ to $2 \times 10^{-6}$ $\mathrm{M}$ with $\mathrm{RSD} \leq 4.6 \%$ [9]. 
A simple, direct and very sensitive differential pulse anodic stripping voltammetric analysis (DPASVA) of selenium(IV) in bulk and in dosage formulations using a gold electrode multimodified with a mixture of $\left\{3,3^{\prime}-\right.$ diaminobenzidine. $4 \mathrm{HCl}\left(\mathrm{D}_{\mathrm{ab}}\right)$ and vitamin $\mathrm{E}\left(\mathrm{V}_{\mathrm{E}}\right)$ -Nafion $\left(\mathrm{GEMD}_{\mathrm{ab}} \mathrm{V}_{\mathrm{E}} \mathrm{N}\right)$ has been studied Liner calibration graph was obtained in the concentration ranges of $1 \times 10^{-9}-1 \times 10^{-6} \mathrm{~mol} / \mathrm{L}$ with relative standard deviations (RSD) $4.8 \%$ [10].

Differential pulse anodic stripping voltammetric analysis (DPASVA) of selenium(IV) using a gold electrode modified with o-Phenylenediaminenafion (GEMO-PN) has been studied. Liner calibration graph, $\mathrm{I}_{\mathrm{p}}=\mathrm{f}\left(\mathrm{C}_{\mathrm{Se}^{4+}}\right)$ was obtained in the concentration ranges of 3.948 to $78.96 \mathrm{ng} / \mathrm{mL}$ with relative standard deviations (RSD) $\leq 3.8 \%$, and the detection limit was $0.048 \mathrm{ng} / \mathrm{mL}$ [11].

The effect of gold electrode modified with 2,3Diaminonaphthalene $\left(\mathrm{GEM}_{\mathrm{DAN}} \mathrm{N}\right)$ and gold electrode multi-modified with a mixture ophenylenediamine and 2,3-diaminonaphthalenenafion $\left(\mathrm{GEM}_{\mathrm{DAN}-\mathrm{OPDA}} \mathrm{N}\right)$ on determination of selenium (IV) using differential pulse anodic stripping voltammetric analysis (DPASVA) has been studied. Selenium (IV) was determined. liner calibration graph, were obtained in the concentration ranges of $5 \times 10^{-8}-1 \times 10^{-6} \mathrm{M}(3.948$ $78.96 \mathrm{ng} / \mathrm{mL}$ ) with relative standard deviations (RSD) $\leq 4.2 \%$, the detection limit was 0.056 $\mathrm{ng} / \mathrm{mL}$ on $\mathrm{GEM}_{\mathrm{DAN}} \mathrm{N}$ and the concentration ranges of $1 \times 10^{-9}-1 \times 10^{-6} \mathrm{M}(0.07896-78.96$ $\mathrm{ng} / \mathrm{mL}$ ) with relative standard deviations
(RSD) $\leq 5.0 \%$, the detection limit was 0.0012 $\mathrm{ng} / \mathrm{mL}$ on $\mathrm{GEM}_{\text {DAN-OPDA }} \mathrm{N}$ [12].

Spectrophotometric determination of selenium (IV) with 2-Mercaptobenzothiazol was also suited [13]. Dispersive liquid-liquid microextraction using diethyldithiocarbamate as a chelating agent and the dried-spot technique for the determination of $\mathrm{Fe}, \mathrm{Co}, \mathrm{Ni}, \mathrm{Cu}, \mathrm{Zn}, \mathrm{Se}$ and $\mathrm{Pb}$ by energydispersive X-ray fluorescence spectrometry [14].

In the present work, the effect of gold electrode modified with sodium diethyldithiocarbamateNafion $\left(\mathrm{GEM}_{\text {DDTC }}\right)$ using differential pulse anodic stripping voltammetric analysis (DPASVA) has been studied.

\section{Experimental}

\section{Reagents}

Nafion perfluorinated ion-exchange resin in ethanol $(3 \% \mathrm{v} / \mathrm{v})$ was purchased from Aldrich. Sodium diethyldithiocarbamate.tryhidrate, $\mathrm{NaS}_{2} \mathrm{CN}\left(\mathrm{C}_{2} \mathrm{H}_{5}\right)_{2} .3 \mathrm{H}_{2} \mathrm{O}$, mol. mass $225.3 \mathrm{~g}$ (Scheme1) was from SIGMA. $\mathrm{H}_{2} \mathrm{SeO}_{3}$ and all other reagents were of analytical grade from Merck [15]. An $\mathrm{HClO}_{4}$ solution $0.10 \mathrm{M}$ and $\mathrm{HCl}$ $0.002 \mathrm{M}$ were used at $\mathrm{pH}=0.22$. A stock solution (a) of $\mathrm{Se}(\mathrm{IV}): 789.6 \mu \mathrm{g} / \mathrm{mL}(0.01 \mathrm{~mol} / \mathrm{L})$ and a stock solution (b) of $\mathrm{Se}(\mathrm{IV}): 7.896 \mu \mathrm{g} / \mathrm{mL}(0.1$ $\mathrm{mmol} / \mathrm{L}$ ) were prepared using $\mathrm{HClO}_{4}$ solution. A working solution for voltammetric investigations was prepared by dilution of the stock solution of $\mathrm{Se}\left(\mathrm{IV}\right.$ ) (a or b) with $\mathrm{HClO}_{4}$ solution.

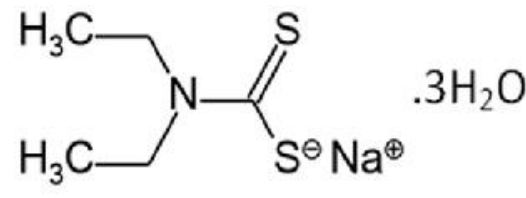

Scheme 1: Sodium diethyldithiocarbamate, $\left(\mathrm{NaS}_{2} \mathrm{CN}\left(\mathrm{C}_{2} \mathrm{H}_{5}\right)_{2} .3 \mathrm{H}_{2} \mathrm{O}\right)$ 


\section{Apparatus}

A polarograghic analyzer, model PRG-5 (Tacussel), with increasing amplitude pulses was used for differential detection of current and for superimposing constant amplitude pulses of negative or positive polarity and pulses of linearly increasing amplitude as the source of scanning voltage. A programmer model POLARMAX-78, and a recorder model ECOSRIPT (Tacussel) were also used. A rotating disk gold electrode (RDGE) model DI-65-14 was used as a working electrode. The reference electrode was $\mathrm{Ag} / \mathrm{AgCl}$ model BJC. The solution was stirred with a rotating electrode and was kept in a thermostat at $25^{\circ} \mathrm{C}$. The diluter pipette model DIP-1 (Shimadzu), having $100 \mu \mathrm{L}$ sample syringe and five continuously adjustable pipettes covering a volume range from 20 to 5000 $\mu \mathrm{L}$ (model PIPTMAN P, GILSON), and a micro syringe which size $10 \mu \mathrm{L}$ were used for preparation of the experimental solutions.

\section{Preparation of modified gold electrode $\left(\right.$ GEM $\left._{\text {DDTC }} \mathbf{N}\right)$.}

Gold electrode was first polished, rinsed with deionized water and ultrasonicated successively in a 1:1 aqueous solution of nitric acid and an ethanol solution for $3 \mathrm{~min}$ and then dried. A modified solution was prepared by putting $1 \mathrm{~mL}$ of DDTC $(2.5 \mathrm{mg} / \mathrm{mL})$ and $3 \mathrm{~mL}$ of Nafion-Ethanol solution $(10 \% \mathrm{v} / \mathrm{v})$ in $10 \mathrm{~mL}$ volumetric flask, then the volume was diluted to the mark with ethanol (this solution contents $0.25 \mathrm{mg} / \mathrm{mL}$ DDTC and $3 \% \mathrm{v} / \mathrm{v}$ Nafion). A modified gold electrode was prepared by placing $10 \mu \mathrm{L}$ from modified solution onto the dry electrode with a micro syringe. The electrode was dried to evaporate the solvent and rinsed with deionized water.

\section{Sample preparation}

A commercial formulations (as tablet) were used for the analysis of Se(IV) by using DPASVA with $\left(\mathrm{GEM}_{\mathrm{DDTC}} \mathrm{N}\right)$. The pharmaceutical formulations were subjected to the analytical procedures:
(1) DamVita Silver Plus tablets, Ultra Medica, Sydnaya - SYRIA, Each tablet contains: $70 \mu \mathrm{g}$ Selenium.

(2) Daily-Vit tablets, Biomed, Damascus SYRIA, Each tablet contains: $70 \mu \mathrm{g}$ Selenium.

(3) Adult Vit Silver tablets, Afhamea, Hama SYRIA, Each tablet contains: $25 \mu \mathrm{g}$ Selenium.

(4) Cenvite tablets, Pharmasyr Co., Damascus SYRIA, Each tablet contains: $25 \mu \mathrm{g}$ Selenium.

(5) Cenvite Silver tablets, Pharmasyr Co., Damascus - SYRIA, Each tablet contains: $20 \mu \mathrm{g}$ Selenium.

Three tablets of each studied pharmaceutical formulations were placed in the crucible of platinum, burning it until the flame was ended, then crushed and dissolved with $10 \mathrm{~mL}$ nitric acid $(65 \%)$. After that, it was heated until the drought, then dissolved with $\mathrm{HClO}_{4}$ solution and filtered over a $100 \mathrm{~mL}$ flask and diluting to $100 \mathrm{~mL}$ with $\mathrm{HClO}_{4}$ solution. Five stock solutions of pharmaceuticals: DamVita Silver Plus, Daily-Vit, Adult Vit Silver, Cenvite and Cenvite Silver which content: 2100, 2100, 750, 750 and $600 \mathrm{ng} / \mathrm{mL}$ of $\mathrm{Se}(\mathrm{IV})$, respectively were studied.

\section{Working solutions of pharmaceuticals}

These solutions were prepared by diluting 1.19, $1.19,3.33,3.33$ and $4.17 \mathrm{~mL}$ of stock solutions of pharmaceuticals respectively to $100 \mathrm{~mL}$ with $\mathrm{HClO}_{4}$ solution (each one content $25 \mathrm{ng} / \mathrm{mL}$ selenium).

\section{Working standard additions solutions of pharmaceuticals}

These solutions were prepared as the follows: same mentioned volumes of stock solutions of pharmaceuticals with $0.000,0.100,0.200,0.400$ and $0.600 \mathrm{~mL}$ from stock solution (b) of selenium and diluting to $100 \mathrm{~mL}$ with $\mathrm{HClO}_{4}$ solution; each one content $25 \mathrm{ng} / \mathrm{mL}$ selenium (from pharmaceutical formulations) with 7.896, 15.792, 31.584 and $47.376 \mathrm{ng} / \mathrm{mL}$ selenium from standard additions solutions of $\mathrm{Se}(\mathrm{IV})$, respectively. 


\section{Procedure}

A $10 \mathrm{~mL}$ volume of a working solution containing an appropriate concentration of Se(IV) was transferred into an electrochemical cell. The accumulation potential $(-350 \mathrm{mV})$ was applied to the modified electrode for a certain time. The potential scanned was from +0.00 to $+1250 \mathrm{mV}$ by differential pulse anodic stripping voltammetry using the auto-scan facility. The peak height was measured at $990-1010 \mathrm{mV}$.

\section{Results and Discussion}

\section{Voltammetric behavior}

The differential pulse anodic stripping voltammograms using the procedure described above with a bare $\mathrm{Au}$ electrode $\left(\mathrm{C}_{\mathrm{Se}(\mathrm{IV})} \geq 1 \times 10^{-4}\right.$ $\mathrm{mol} / \mathrm{L}, \mathrm{RSD}=6.8 \%$ ), while an electrode modified with $\left(\mathrm{GEM}_{\mathrm{DDTC}} \mathrm{N}\right)$ shows that the peak potential shifted slightly from $990 \mathrm{mV}$ to $1010 \mathrm{mV}$ and the sensitivity increased $\left(\mathrm{C}_{\mathrm{Se}(\mathrm{IV})} \geq 2.5 \times 10^{-8} \mathrm{~mol} / \mathrm{L}\right)$ when the $\left(\mathrm{GEM}_{\mathrm{DDTC}} \mathrm{N}\right)$ was introduced to modify the coating.

\section{Effect of modified electrode composition}

The effect of the Nafion and sodium diethyldithiocarbamate, tryhidrate, concentrations in modified solution for formation gold electrode modified with sodium diethyldithiocarbamate .tryhidrate-Nafion $\left(\mathrm{GEM}_{\text {DDTC }} \mathrm{N}\right)$ on the peak current were studied. The peak current reached its maximum when the concentration Nafion is $3 \%$ $\mathrm{v} / \mathrm{v}$ and DDTC is $2.5 \mathrm{mg} / \mathrm{mL}$.

\section{Effect of the accumulation potential}

The dependence of the differential pulse anodic stripping peak current on the accumulation potential was examined. It was found that the maximum response for selenium (IV) occurs with accumulation potentials equal to $-0.350 \mathrm{~V}$, see (Figures $1 \& 2$ ).
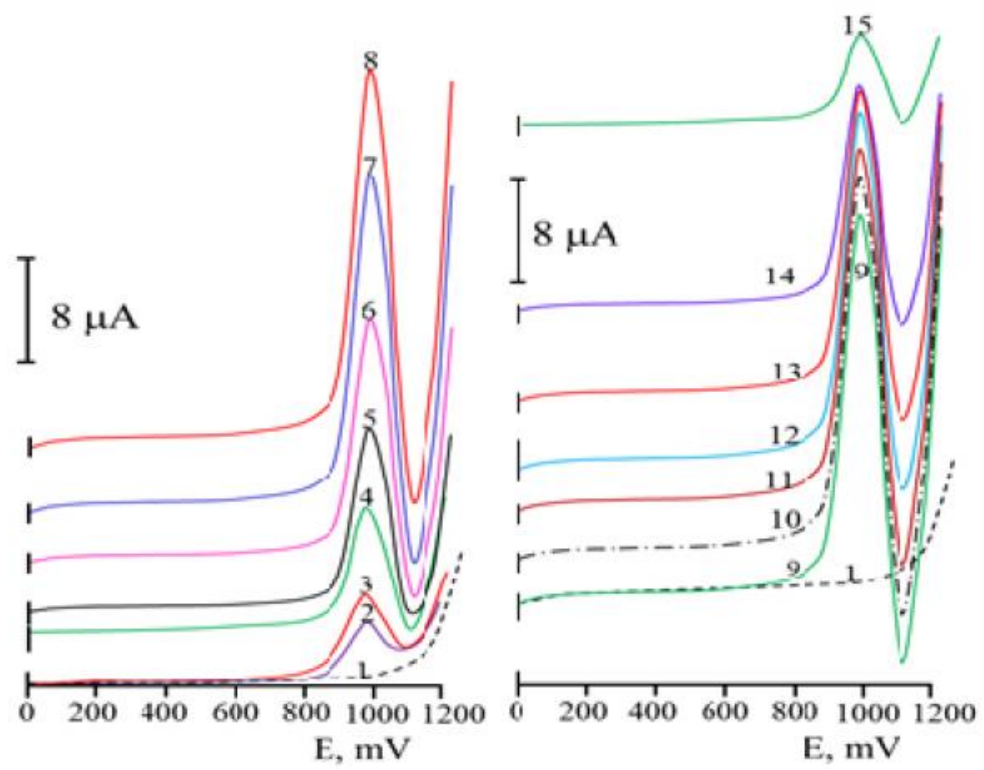

Fig.1. Effect of accumulation potential on differential pulse anodic stripping voltammograms of Se(IV) $78.96 \mathrm{ng} / \mathrm{mL}$ using DDTC-Nafion modified gold electrode, $\mathrm{pH}=0.22$, scan rate $10 \mathrm{mV} / \mathrm{s}$ and temperature $25^{\circ} \pm 0.5^{\circ} \mathrm{C}$ at of accumulation potential: 1) Electrolyte $\left.\left(0.1 \mathrm{M} \mathrm{HClO}_{4}+0.002 \mathrm{M} \mathrm{HCl}\right), 2\right)-50 \mathrm{mV}$, 3) $-100 \mathrm{mV}$, 4) $-150 \mathrm{mV}, 5)-200 \mathrm{mV}$, 6) $-250 \mathrm{mV}, 7)-300 \mathrm{mV}, 8)-325 \mathrm{mV}$, 9)-350mV ,10) $-375 \mathrm{mV}$, 11) $-400 \mathrm{mV}$, 12) $-425 \mathrm{mV}, 13)-450 \mathrm{mV}, 14)-500 \mathrm{mV}, 15)-600 \mathrm{mV}$. 
Int. J. Curr. Res. Chem. Pharm. Sci. (2020). 7(7): 11-23

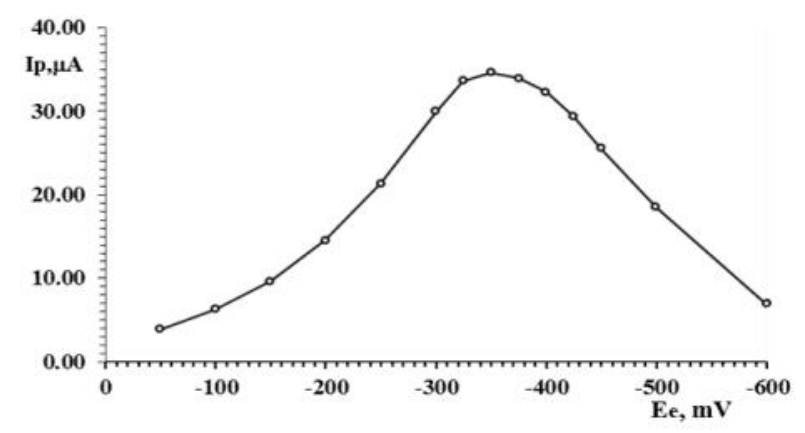

Fig.2. Effect of accumulation potential on differential pulse anodic stripping voltammograms of Se(IV) $78.96 \mathrm{ng} / \mathrm{mL}$ using DDTC-Nafion modified gold electrode, $\mathrm{pH}=0.22$, scan rate $10 \mathrm{mV} / \mathrm{s}$ and temperature $\left.25^{\circ} \pm 0.5^{\circ} \mathrm{C}\right)$.

\section{Effect of accumulation time}

The dependence of the peak current on the accumulation time for $\mathrm{Se}(\mathrm{IV})$ concentrations was studied. The peak current increases with increasing accumulation time. The current is nearly linear from 50 to $400 \mathrm{~s}$. Various parameters (electrolyte, accumulation potential, $\mathrm{pH}$ solution, scan rate, waiting time, stirring speed of electrode, initial potential, final potential and composition of modified solution) affecting the $\mathrm{Se}(\mathrm{IV})$ determination were examined, see (Figure 3). The optimum parameters for DPASV determination of selenium (IV) were selected and presented in the (Table 1).

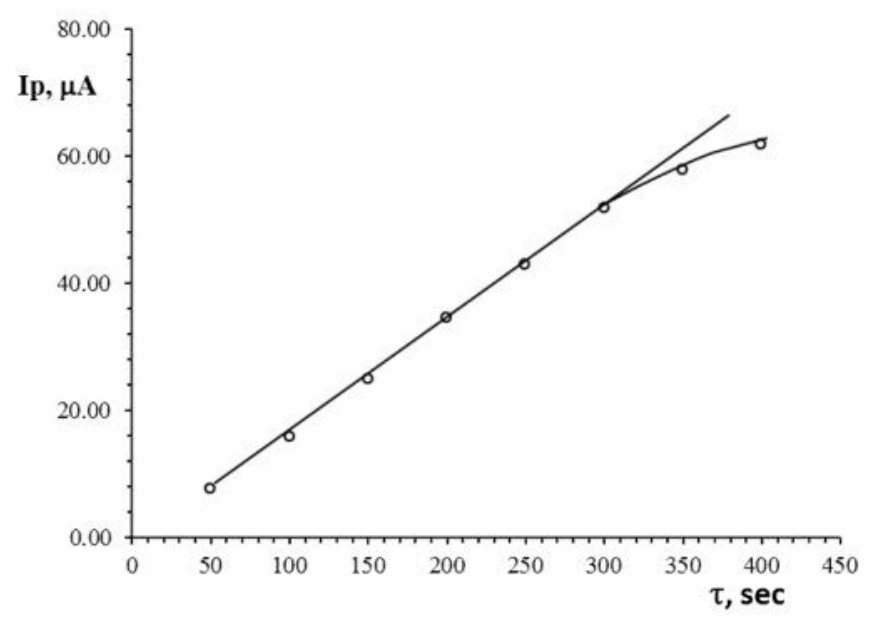

Fig.3. Effect of accumulation time on differential pulse anodic stripping voltammograms of Se(IV) 78.96 $\mathrm{ng} / \mathrm{mL}$ using DDTC-Nafion modified gold electrode (accumulation potential $-350 \mathrm{mv}, \mathrm{pH}=0.22$, scan rate $10 \mathrm{mV} / \mathrm{s}$ and temperature $25^{\circ} \pm 0.5^{\circ} \mathrm{C}$ ). 
Int. J. Curr. Res. Chem. Pharm. Sci. (2020). 7(7): 11-23

Table 1: The optimum parameters established for differential pulse anodic stripping voltammetric determination of selenium(IV).

\begin{tabular}{|c|c|}
\hline Parameters & Operating modes \\
\hline Accumulation (deposition) time & $200 \mathrm{~s}$ \\
Accumulation potential & $-350 \mathrm{~m} \mathrm{~V}$ \\
Supporting electrolyte & $0.10 \mathrm{M} \mathrm{HClO}$ \& $0.002 \mathrm{M} \mathrm{HCl}$ \\
Indicator electrode & Rotating disk gold electrode (RDGE) \\
pH solution & 0.22 \\
Modified electrode composition & Nafion-Ethanol \\
Waiting time & $5 \mathrm{~s}$ \\
Drop modified size & $10 \mu \mathrm{L}$ \\
Initial potential & $+000 \mathrm{mV}$ \\
Final potential & $+1200 \mathrm{mV}$ \\
Peak potential & $990-1010 \mathrm{mV}$ \\
Scan rate & $10 \mathrm{mV} / \mathrm{s}$ \\
Stirring speed & $1000 \mathrm{rpm}$ \\
Temperature of solution & $25^{\circ} \pm 0.5^{\circ} \mathrm{C}$ \\
\hline
\end{tabular}

\section{Analytical results}

The analytical curves, $I_{p}=f\left(C_{S e(I V)}\right)$, for the determination of $\mathrm{Se}(\mathrm{IV})$ in presence of $0.10 \mathrm{M}$ $\mathrm{HClO}_{4}$ and $0.002 \mathrm{M}$ HCL on $\left(\mathrm{GEM}_{\mathrm{DDTC}} \mathrm{N}\right)$ by (DPASVA) showed linear proportionality over the concentration range from 1.974 to 78.96 $\mathrm{ng} / \mathrm{mL}\left(2.5 \times 10^{-8}\right.$ to $\left.1 \times 10^{-6} \mathrm{~mol} / \mathrm{L}\right)$ of $\mathrm{Se}(\mathrm{IV})$ with accumulation (deposition) time 200 s., see (Figure 4). Regression equations and correlation coefficient were as the follows: $y=0.4375 x+$ $0.0006\left(\mathrm{R}^{2}=0.9997\right)$ in this method a very low concentration $1.974 \mathrm{ng} / \mathrm{mL}\left(2.5 \times 10^{-8} \mathrm{~mol} / \mathrm{L}\right)$ with relative standard deviation not exceed $\pm 4.0 \%$ (Table 2). This method showed a very sensitive results for the determination of $\mathrm{Se}$ (IV) on $\left(\mathrm{GEM}_{\mathrm{DDTC}} \mathrm{N}\right)$ more than that obtained using bare gold, GEM ${ }_{\text {DAN }} \mathrm{N}$ and GEM OPDA $\mathrm{N}$ electrodes (the sensitivity was increased about 4000 times and about 2 times, respectively). 

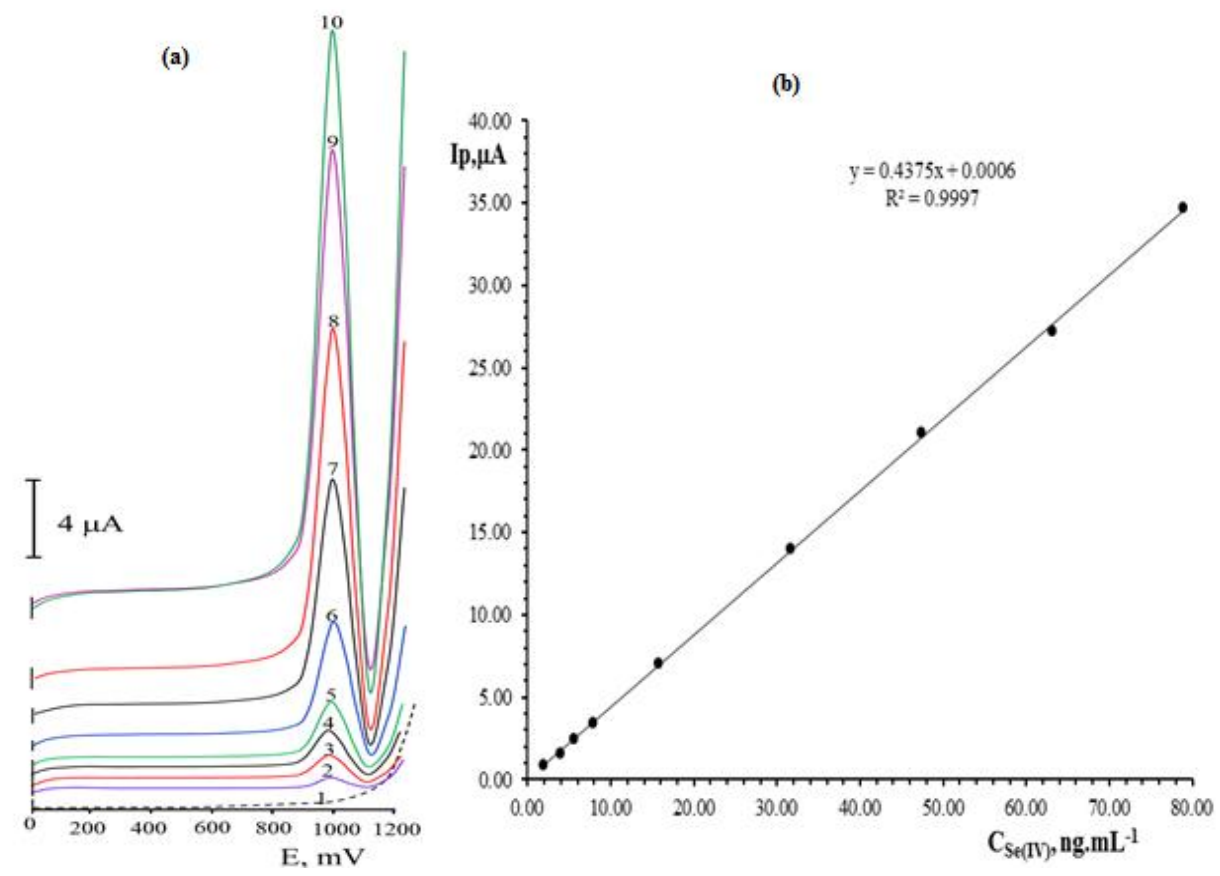

Fig.4. (a) Differential pulse anodic stripping voltammograms of Se(IV) on DDTC-Nafion modified gold electrode at $\mathrm{pH}=0.22$ when $\mathrm{C}_{\mathrm{Se}(\mathrm{IV})}$ : 1- electrolyte, 2-1.974, 3- 3.948, 4- 5.5272, 5- 7.896, 6- 15.792, 731.584, 8- 47.376, 9-63.168, and 10- $78.96 \mathrm{ng} / \mathrm{mL}$. (b) $\mathrm{I}_{\mathrm{p}}=\mathrm{f}\left(\mathrm{C}_{\mathrm{Se}(\mathrm{IV})}\right)$ for the determination of $\mathrm{Se}(\mathrm{IV})$ in presence of $0.10 \mathrm{M} \mathrm{HClO}_{4}$ and $0.002 \mathrm{M} \mathrm{HCl}$ by DPASVA using a DDTC-Nafion modified gold electrode (accumulation time $200 \mathrm{~s}$, accumulation potential $-350 \mathrm{mV}, \mathrm{pH}=0.22$, scan rate $10 \mathrm{mV} / \mathrm{s}$ and temperature $\left.25^{\circ} \pm 0.5^{\circ} \mathrm{C}\right)$.

Table 2: Determination of selenium(IV) by DPASVA on a DDTC-Nafion modified gold electrode (accumulation time $200 \mathrm{~s}$, accumulation potential $-350 \mathrm{mV}, \mathrm{pH}=0.22$, scan rate $10 \mathrm{mV} / \mathrm{s}$, temperature $25^{\circ} \pm$ $0.5^{\circ} \mathrm{C}$ and $\left.\mathrm{n}=5, \mathrm{t}=2.776\right)$.

\begin{tabular}{|c|c|c|c|c|c|}
\hline $\begin{array}{l}\mathbf{x}_{\mathbf{i}}, \mathbf{n g} / \mathbf{m L} \\
\text { (taken) }\end{array}$ & $\begin{array}{l}\bar{x}, \mathbf{n g} / \mathbf{m L} \\
\text { (found) }\end{array}$ & $\begin{array}{c}\text { SD, } \\
\text { ng/mL }\end{array}$ &, $\mathbf{n g} / \mathbf{m L} \frac{S D}{\sqrt{n}}$ & $\bar{x} \pm \frac{t . S D}{\sqrt{n}}, \mathbf{n g} / \mathbf{m L}$ & RSD \% \\
\hline 1.974 & 1.959 & 0.078 & 0.035 & $1.959 \pm 0.097$ & 4.0 \\
\hline 3.948 & 3.765 & 0.139 & 0.062 & $3.765 \pm 0.173$ & 3.7 \\
\hline 5.527 & 5.525 & 0.188 & 0.084 & $5.525 \pm 0.233$ & 3.4 \\
\hline 7.896 & 7.778 & 0.257 & 0.115 & $7.778 \pm 0.319$ & 3.3 \\
\hline 15.792 & 15.999 & 0.480 & 0.215 & $15.999 \pm 0.596$ & 3.0 \\
\hline 31.584 & 31.907 & 0.925 & 0.414 & $31.907 \pm 1.149$ & 2.9 \\
\hline 47.376 & 47.999 & 1.248 & 0.558 & $47.999 \pm 1.549$ & 2.6 \\
\hline 63.168 & 62.170 & 1.492 & 0.667 & $62.170 \pm 1.852$ & 2.4 \\
\hline 78.960 & 79.244 & 1.585 & 0.709 & $79.244 \pm 1.968$ & 2.0 \\
\hline
\end{tabular}


Int. J. Curr. Res. Chem. Pharm. Sci. (2020). 7(7): 11-23

The proposed mechanism of $\mathrm{Se}(\mathrm{IV})$ on $\left(\right.$ GEM $\left._{\text {DDTC }} \mathbf{N}\right)$

The disk of gold electrode modified was developed by sodium diethyldithiocarbamate. This reagent attracts selenium and is associated with it on the surface of the electrode, forming a complex ratio of $4: 1 ;$ [( DDTC $)_{4}$ : Se]. On the surface of the electrode by applying accumulation potential $-350 \mathrm{mV}$, after which the oxidation of the metallic selenium to the quaternary selenium as the following mechanism.

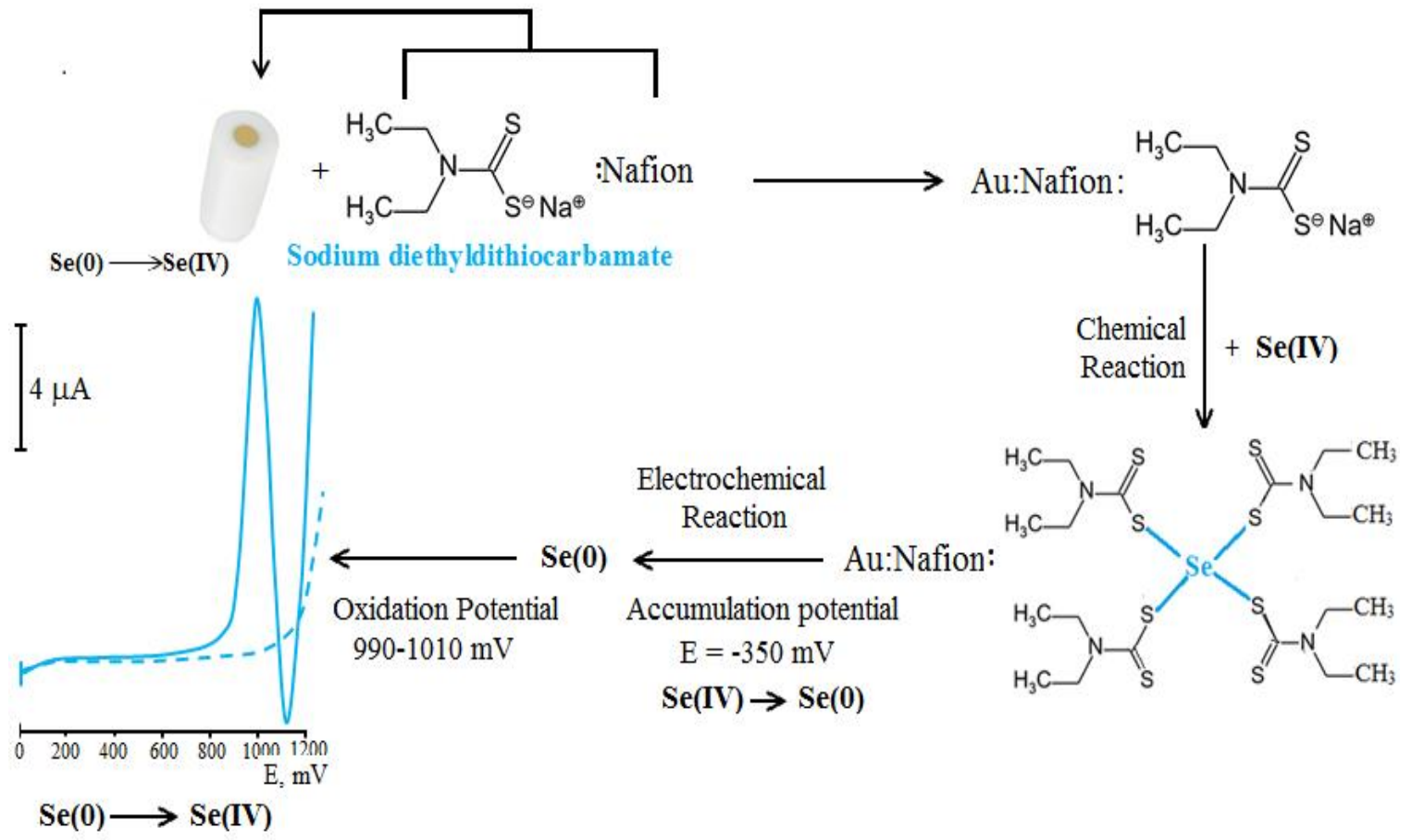

Scheme 2: Electrochemical mechanisms of selenium on modified gold electrode $\left(G_{E M D T C N}\right)$.

\section{Applications}

Many applications for the determination of Se(IV) in some pharmaceutical preparations by DPASVA on a $\left(\mathrm{GEM}_{\mathrm{DDTC}} \mathrm{N}\right)$ using the optimum conditions were proposed. Standard addition

curves for determination of $\mathrm{Se}(\mathrm{IV})$ in different pharmaceutical preparations (DamVita Silver Plus, Daily-Vit, Adult Vit Silver, Cenvite and Cenvite Silver) were used. Regression equations and correlation coefficients were included in (Table 3). The amount (m) of Se(IV) in one tablet by $\mathrm{g} / \mathrm{tab}$ calculated from the following relationship: $\mathrm{m}=\mathrm{h} . \mathrm{m}$, where: $\mathrm{m}$ ' is the amount of
Se(IV) in tablet, which calculated from the standard additions curve according to the following regression equation: $\mathrm{y}=\mathrm{a} \cdot \mathrm{x}+\mathrm{b}$; when $\mathrm{y}=0 ; \mathrm{m}^{\prime}=\mathrm{x}=\mathrm{b} / \mathrm{a}=$ intercept/slope $(\mathrm{ng} / \mathrm{ml})$ and $\mathrm{h}$ conversion factor is equal to $2.8,2.8,1.0,1.0$ and 0.8 for all pharmaceuticals content $70,70,25,25$ and $20 \mathrm{~g} / \mathrm{tab}$, respectively. The results of quantitative analysis for $\mathrm{Se}(\mathrm{IV})$ in the pharmaceutical preparations using this method included in (Table 4). The proposed method was simple, economic, accurate and successfully applied to the determination of Se(IV) in pharmaceuticals. The results obtained agree well with the contents stated on the labels. 
Int. J. Curr. Res. Chem. Pharm. Sci. (2020). 7(7): 11-23

Table 3: Regression equations and correlation coefficients for determination of $\mathrm{C}_{\mathrm{Se}(\mathrm{IV})}$ in pharmaceutical preparations using DPASV on $\left(\mathrm{GEM}_{\mathrm{DDTC}} \mathrm{N}\right)$ (accumulation time $200 \mathrm{~s}$, accumulation potential $-350 \mathrm{mV}$, $\mathrm{pH}=0.22$, scan rate $10 \mathrm{mV} / \mathrm{s}$, temperature $25^{\circ} \pm 0.5^{\circ} \mathrm{C}$ and $\mathrm{n}=5$ ).

\begin{tabular}{|c|c|c|c|c|c|}
\hline \multirow[b]{2}{*}{$\begin{array}{l}\text { Pharmaceutical } \\
\text { preparations }\end{array}$} & \multirow{2}{*}{$\begin{array}{c}\mathrm{C}_{\text {Se(IV) }} \\
\text { in } \\
\text { tab., } \\
\text { g }\end{array}$} & \multicolumn{4}{|c|}{ Operating modes } \\
\hline & & $\begin{array}{l}\text { Regression } \\
\text { equations* }\end{array}$ & $\begin{array}{l}\text { Correlation } \\
\text { coefficients }\end{array}$ & $\mathbf{m}^{\prime}, \mathbf{n g} / \mathbf{m L}$ & $\begin{array}{l}\text { Amount of } \mathrm{Se}^{4+} \\
(\mathrm{m}), \mathrm{g} / \mathrm{tab} .\end{array}$ \\
\hline $\begin{array}{c}\text { Dam Vita Silver Plus } \\
\text { tablets, Ultra Medica, } \\
\text { Sydnaya-SYRIA }\end{array}$ & 70 & $y=0.4377 x+11.226$ & $\mathrm{R}^{2}=0.9998$ & 25.65 & $\mathrm{~m}=2.8 \mathrm{~m}^{\prime}=71.81$ \\
\hline $\begin{array}{c}\text { Daily-Vittablets, Biomed, } \\
\text { Damascus-SYRIA }\end{array}$ & 70 & $y=0.4373 x+11.259$ & $\mathrm{R}^{2}=0.9992$ & 25.75 & $\mathrm{~m}=2.8 \mathrm{~m}^{\prime}=72.09$ \\
\hline $\begin{array}{l}\text { Adult Vit Silvertablets, } \\
\text { Afhamea, Hama-SYRIA }\end{array}$ & 25 & $y=0.4378 x+10.852$ & $\mathrm{R}^{2}=0.9997$ & 24.79 & $\mathrm{~m}=1.0 \mathrm{~m}^{\prime}=24.79$ \\
\hline $\begin{array}{l}\text { Cenvitetablets, Pharmasyr } \\
\text { Co., Damascus - SYRIA }\end{array}$ & 25 & $y=0.4370 x+11.112$ & $\mathrm{R}^{2}=0.9995$ & 25.43 & $\mathrm{~m}=1.0 \mathrm{~m}^{\prime}=25.43$ \\
\hline $\begin{array}{c}\text { Cenvite Silver tablets, } \\
\text { Pharmasyr Co., } \\
\text { Damascus-SYRIA }\end{array}$ & 20 & $y=0.4376 x+11.353$ & $\mathrm{R}^{2}=0.9991$ & 25.94 & $\mathrm{~m}=0.8 \mathrm{~m}^{\prime}=20.76$ \\
\hline
\end{tabular}

Table 4: Determination of $\mathrm{Se}(\mathrm{IV})$ in pharmaceutical preparations using DPASV on a $\left(\mathrm{GEM}_{\mathrm{DDTC}} \mathrm{N}\right)$ (accumulation time $200 \mathrm{~s}$, accumulation potential $-350 \mathrm{mV}, \mathrm{pH}=0.22$, scan rate $10 \mathrm{mV} / \mathrm{s}$, temperature $25^{\circ} \pm$ $0.5^{\circ} \mathrm{C}$ and $\left.\mathrm{n}=5\right)$.

\begin{tabular}{|c|c|c|c|c|}
\hline Commercial name & Contents, g/tab. & $\bar{x}$, g/tab. & RSD\% & Assay \% \\
\hline $\begin{array}{c}\text { Dam Vita Silver Plus } \\
\text { tablets, Ultra Medica, } \\
\text { Sydnaya-SYRIA }\end{array}$ & 70 & 71.81 & 2.6 & 102.59 \\
\hline $\begin{array}{c}\text { Daily-Vit tablets, } \\
\text { Biomed, Damascus- } \\
\text { SYRIA }\end{array}$ & 70 & 72.09 & 2.4 & 102.99 \\
\hline $\begin{array}{c}\text { Adult Vit Silver tablets, } \\
\text { Afhamea, Hama-SYRIA }\end{array}$ & 25 & 24.79 & 2.9 & 99.16 \\
\hline $\begin{array}{c}\text { Cenvite tablets, } \\
\text { Pharmasyr Co., }\end{array}$ & 25 & 25.43 & 3.0 & 101.72 \\
\hline $\begin{array}{c}\text { Damascus - SYRIA } \\
\text { Cenvite Silver tablets, } \\
\begin{array}{c}\text { Pharmasyr Co., } \\
\text { Damascus-SYRIA }\end{array}\end{array}$ & 20 & 20.76 & 3.2 & 103.80 \\
\hline
\end{tabular}




\section{Validation of proposed method}

The developed method for simultaneous estimation of $\mathrm{Se}$ (IV) has been validated in accordance with the International Conference on Harmonization guidelines (ICH) [16].

\section{Selectivity}

Selectivity test determines the effect of excipients on the assay result. The results of the tests proved that the effect of the presence of common excipients are no interference.

\section{Linearity}

In the proposed methods, linear plots $(n=5)$ with good correlation coefficients were obtained in the concentration ranges of $y=0.4375 x+0.0006$ $\left(\mathrm{R}^{2}=0.9997\right)$ on a $\left(\mathrm{GEM}_{\mathrm{DDTC}} \mathrm{N}\right)$ for the concentration from 1.974 to $78.96 \mathrm{ng} / \mathrm{mL}$. In this method a very low concentration $1.974 \mathrm{ng} / \mathrm{mL}$ $\left(2.5 \times 10^{-8} \mathrm{~mol} / \mathrm{L}\right)$ of $\mathrm{Se}(\mathrm{IV})$.

\section{Precision and Accuracy}

The precision and accuracy of proposed method was checked by recovery study by addition of standard Se(IV) solution to pre-analyzed sample solution at three different concentration levels (80\%, 100\% and 120\%) within the range of linearity for $\mathrm{Se}(\mathrm{IV})$. The basic concentration level of sample solution selected for spiking of the $\mathrm{Se}(\mathrm{IV})$ standard solution was $15.792 \mathrm{ng} / \mathrm{mL}$. The proposed method was validated statistically and through recovery studies, and was successfully applied for the determination of Se(IV) in pure and dosage forms with percent recoveries ranged from $99.8 \%$ to $101.5 \%$ (Table 5).

Table 5 : Results of recovery studies $(n=5)$.

\begin{tabular}{|c|c|}
\hline Level & $\%$ Recovery \\
\hline $80 \%$ & 99.8 \\
$100 \%$ & 100.6 \\
$120 \%$ & 101.5 \\
\hline
\end{tabular}

\section{Repeatability}

The repeatability was evaluated by performing 10 repeat measurements for $5.527 \mathrm{ng} / \mathrm{ml}$ of $\mathrm{Se}(\mathrm{IV})$ using the studied method under the optimum conditions in two concentration ranges. The found amount of Se (IV) $(\bar{x} \pm \mathrm{SD})$ was $5.526 \pm 0.172$ $\mathrm{ng} / \mathrm{ml}$ and the percentage recovery was found to be $99.98 \pm 3.1$ with RSD of 0.031 . These values indicate that the proposed method has high repeatability for Se (IV) analysis.

\section{Sensitivity (LOD and LOQ)}

The limits of detection (LOD) and quantitation (LOQ) were determined using the formula: LOD or $\mathrm{LOQ}=\mathrm{jSD} / \mathrm{b}$, where $\mathrm{j}=3.3$ for LOD and 10 for $\mathrm{LOQ}, \mathrm{SD}$ is the standard deviation of the intercept, and b is the slope. The values of LOD and LOQ for Se(IV) are 0.028 and $0.084 \mathrm{ng} / \mathrm{mL}$, respectively .

\section{Robustness}

The robustness of the method adopted is demonstrated by the constancy of the current peak $\left(I_{P}\right)$ with the deliberated minor change in the experimental parameters such as the change in the concentration of excipients, temperature $\left(25 \pm 5^{\circ} \mathrm{C}\right), \mathrm{pH}(0.22 \pm 0.01)$, accumulation potential $(-350 \pm 5 \mathrm{mV})$ and $\mathrm{C}_{\mathrm{HClO}_{4}}(0.10 \pm 0.01 \mathrm{~mol} / \mathrm{L})$ and $\mathrm{C}_{\mathrm{HCl}}(0.002 \pm 0.0001 \mathrm{~mol} / \mathrm{L})$. Table 6 was indicates the robustness of the proposed method $\left(\mathrm{I}_{\mathrm{p}}\right.$ was measured and assay was calculated for five times). 
Int. J. Curr. Res. Chem. Pharm. Sci. (2020). 7(7): 11-23

Table 6: Robustness of the proposed DPASVA method.

\begin{tabular}{|c|c|}
\hline Experimental parameter & Average recovery $(\%)^{*}$ \\
variation & $\mathrm{C}_{\mathrm{Se}(\mathrm{IV})}=15.792 \mathrm{ng} / \mathrm{mL}$ \\
\hline Temperature & 99.9 \\
$20^{\circ} \mathrm{C}$ & 101.0 \\
$30^{\circ} \mathrm{C}$ & \\
$\mathrm{pH}$ & 100.0 \\
0.21 & 99.8 \\
0.23 & \\
\hline Accumulation potential & 100.7 \\
$-345 \mathrm{mV}$ & 100.4 \\
$-355 \mathrm{mV}$ & \\
$\mathrm{C}_{\mathrm{HClO}}$ & 99.7 \\
$0.09 \mathrm{~mol} / \mathrm{L}$ & 100.6 \\
$0.11 \mathrm{~mol} / \mathrm{L}$ & \\
$\mathrm{C}_{\mathrm{HCl}}$ & 99.9 \\
$0.0019 \mathrm{~mol} / \mathrm{L}$ & 100.4 \\
\hline $0.0021 \mathrm{~mol} / \mathrm{L}$ & \\
\hline
\end{tabular}

\section{Conclusion}

DPASVA of selenium (IV) using $\left(\mathrm{GEM}_{\text {DDTC }} \mathrm{N}\right)$ with an aqueous $\mathrm{HClO}_{4}(0.1 \mathrm{M})$ and $(0.002 \mathrm{M})$ $\mathrm{HCl}$ medium of $\mathrm{pH} 0.22$ according to the optimal conditions was applied, liner calibration graph, $\mathrm{I}_{\mathrm{p}}=\mathrm{f}\left(\mathrm{C}_{\mathrm{Se}^{4+}}\right)$, were obtained in the concentration ranges of $1.974-78.96 \mathrm{ng} / \mathrm{mL}$ with relative standard deviations (RSD) $\leq 4.0 \%$, the detection limit was $0.028 \mathrm{ng} / \mathrm{mL}$ on $\left(\mathrm{GEM}_{\text {DDTC }} \mathrm{N}\right)$. This method showed a good accumulation efficiency for selenium and good resistance to interferences from metal ions as well as those associated with selenium in pharmaceuticals. The results for the determination of $\mathrm{Se}^{4+}$ using $\left(\mathrm{GEM}_{\mathrm{DDTC}} \mathrm{N}\right)$ was more sensitive and accurate than that obtained using bare gold, $\mathrm{GEM}_{\mathrm{DAN}} \mathrm{N}$ and $\mathrm{GEM}_{\mathrm{OPDA}} \mathrm{N}$ electrodes (the sensitivity was increased about 4000 times and about 2 times, respectively).

\section{References}

1. nam R., Toprak Ç., 2004. "Determination of selenium (IV) using o-phenylenediamine by differential pulse polarography/interference of metal ions". Turk J Chem., 28(3):299-309.

2. Wang J., Sun C., 1990. "Adsorption voltammetry of selenium in the presence of o-phenylenediamine". J. Electroanal Chem., 291(1-2):59-66.

3. Mi-Sook W., Jang-Hee Y., Yoon-Bo S., 2005. "Determination of selenium with a poly(1,8-diamino-naphthalene)-modified electrode". Electroanalysis., 17(21):19521958.

4. Stoica A., Babaua G., Iorgulescu E., Marinescu D., Baiulescu G., 2002. "Differrential pulse cathodic stripping voltammetric determination of selenium in pharmaceutical products". J Pharm Biomed Anal. 30(4):1425-1429.

5. Zhihong L., Wenjian Q.,1992. "Determination of trace selenium in the human body by stripping voltammetric method with ophenylene diamine in situ". Acta Universitatis Medicinae Tongji.,21(6):382-384.

6. Soo K., Ruidong Y., 2002. "Differential pulse voltammetric determination of trace $\mathrm{Te}(\mathrm{IV})$ at a poly(3,3'-diaminobenzidine) film modified gold electrode in flow systems". Anal Chim Acta., 453(2):209-220.

7. Hao-Yun Y., Wen Sun I., 2000. "Cathodic stripping voltammetric determination selenium(IV) at a nafion coated mercury film electrode modified with 3,3'diaminobenzidine". Electroanalysis., 12(18): 1476-1480. 
8. Ramadan A.A., Mandil H., Ozoun A., 2011. "Differential pulse anodic stripping voltammetric determination of selenium(IV) with a vitamin E-nafion modified gold electrode". Asian J Chem., 23(2):843-846.

9. Ramadan A.A., Mandil H., Shikh-debes Abdulrahman., 2014. "Differential pulse anodic stripping voltammetric determination of selenium(IV) at a gold electrode modified with 3,3'-diaminobenzidine.4HCl-Nafion". Int J Pharm Pharm Sci., 6(3):148-153.

10. Ramadan A.A., Mandil H., Shikh-debes Abdulrahman., 2017. "Development and validation of differential pulse anodic stripping voltammetric analysis of selenium(IV) in bulk and in dosage formulations at a gold electrode multimodified with a mixture of 3,3'Diaminobenzidine. $4 \mathrm{HCl}$ and vitamin E." , Int J Pharm Pharm Sci., 9(7):97-102.

11. Ramadan A.A., Mandil H., Shikh-debes Abdulrahman., 2018. "Differential pulse anodic stripping voltammetric analysis of selenium(IV) at a gold electrode modified with O-phenylenediamine- nafion". J. Pharm. and Tech., 11(5):2030-2035.

12. Ramadan A.A., Mandil H., Shikh-debes Abdulrahman., 2018. "Differential pulse anodic stripping voltammetric analysis for determination selenium (IV) in Bulk and in dosage formulations using multi-modified gold electrode with a mixture of OPhenylenediamine and 2,3Diaminonaphthalene-Nafion", Journal of Advances in Chemistry, 15(2):6248-6261.

13. Bera B.C., Chakrabartty M.M., 1968. "Spectrophotometric Determination of Selenium with 2-Mercaptobenzothiazole", Analyst, 93:50-55.

14. Kocot K., Zawisza B., Sitko R., 2012. "Dispersive liquid-liquid microextraction using diethyldithiocarbamate as a chelating agent and the dried-spot technique for the determination of $\mathrm{Fe}, \mathrm{Co}, \mathrm{Ni}, \mathrm{Cu}, \mathrm{Zn}, \mathrm{Se}$ and $\mathrm{Pb}$ by energy-dispersive $\mathrm{X}$-ray fluorescence spectrometry", Spectrochimica Acta Part B., $73: 79-83$.

15. Neil J.O., 2001. "The Merck Index, Merck Research Laboratories". 13th Ed., Martindale, Merck.

16. ICH: Proceedings of the International Conference on Harmonization of Technical Requirement of Registration of Pharmaceuticals for Human Use (ICH Harmonized Tripartite Guidelines)., 2000.

\begin{tabular}{|c|l|}
\hline \multicolumn{2}{|c|}{ Access this Article in Online } \\
\hline Q & Website: \\
\hline & www.ijcrcps.com \\
\hline Quick Response Code & Subject: \\
\hline DOI: $10.22192 /$ ijcrcps.2020.07.07.002 \\
\hline
\end{tabular}

How to cite this article:

Abdul Aziz Ramadan, Hasna Mandil, Abdul Rahman Shikh-Debes (2020). Development of Gold Electrode Modified With Sodium Diethyldithiocarbamate-Nafion to Determine Selenium (IV) in Bulk and in Dosage Formulations Using Differential Pulse Anodic Stripping Voltammetric Analysis. Int. J. Curr. Res. Chem. Pharm. Sci. 7(7): 11-23.

DOI: http://dx.doi.org/10.22192/ijcrcps.2020.07.07.002 